\title{
Selection of oleaginous yeasts for fatty acid production
}

\author{
Dennis Lamers ${ }^{1,2^{*}+}$, Nick van Biezen ${ }^{1 \dagger}$, Dirk Martens ${ }^{2}$, Linda Peters ${ }^{1}$, Eric van de Zilver ${ }^{1}$, \\ Nicole Jacobs-van Dreumel ${ }^{1}$, René H. Wijffels ${ }^{2,3}$ and Christien Lokman ${ }^{1}$
}

\begin{abstract}
Background: Oleaginous yeast species are an alternative for the production of lipids or triacylglycerides (TAGs). These yeasts are usually non-pathogenic and able to store TAGs ranging from $20 \%$ to $70 \%$ of their cell mass depending on culture conditions. TAGs originating from oleaginous yeasts can be used as the so-called second generation biofuels, which are based on non-food competing "waste carbon sources".
\end{abstract}

Results: In this study the selection of potentially new interesting oleaginous yeast strains is described. Important selection criteria were: a broad maximum temperature and $\mathrm{pH}$ range for growth (robustness of the strain), a broad spectrum of carbon sources that can be metabolized (preferably including C-5 sugars), a high total fatty acid content in combination with a low glycogen content and genetic accessibility.

Conclusions: Based on these selection criteria, among 24 screened species, Schwanniomyces occidentalis (Debaromyces occidentalis) CBS2864 was selected as a promising strain for the production of high amounts of lipids.

Keywords: Oleaginous yeast, Schwanniomyces occidentalis, Lipid production, TAG

\section{Background}

Mineral and vegetable oil is a crucial resource for the modern human civilization, but the worldwide amount is depleting rapidly and alternatives need to be explored. An interesting alternative to decrease the dependency of western societies on these fossil and vegetable sources might be the use of oleaginous micro-organisms as described by various authors [1-3]. Lipids isolated from oleaginous micro-organisms can be used as components in coatings, paints, personal care products, production of fine chemicals and biodiesel thereby decreasing the dependency on vegetable and mineral oil [4-7]. Fatty Acid Methyl Esters originating from the lipids of oleaginous micro-organisms (e.g. algae, yeast and fungi) show identical fuelling properties compared to conventional diesel and could be used in modern cars without major adaptations [8]. At this moment the majority of

\footnotetext{
* Correspondence: dennis.lamers@han.nl

${ }^{\dagger}$ Equal contributors

'HAN BioCentre, University of Applied Sciences, P.O. Box 6960, 6503 GL Nijmegen, The Netherlands

${ }^{2}$ Bioprocess Engineering, Wageningen University and Research Centre, P.O.

Box 8129, 6700 EV Wageningen, The Netherlands

Full list of author information is available at the end of the article
}

biodiesel is produced from lipids, which are also used in the food chain and thus compete with food for agricultural land [7]. Therefore, oleaginous micro-organisms growing on agricultural waste residues are an attractive class of micro-organisms for lipid production.

An interesting class of oleaginous micro-organisms are yeasts. Oleaginous yeasts are able to store large quantities of TAGs in the form of lipid bodies in the cells. Typical lipid contents range from $20 \%$ to $76 \%$ depending species and culture conditions. Oleaginous yeasts strains studied today are e.g. Yarrowia lipolytica, Candida 107, Rhodotorula glutinis, Rhodosporidium toruloides, Cryptococcus curvatus, Trichosporon pullulan and Lipomyces lipofer. Screening studies are still performed, leading to the identification of several new oleaginous yeast species [1,9-11]. Lipid accumulation is triggered by a nutrient limitation combined with an excess of carbon. Mostly nitrogen limitation is used to trigger lipid accumulation, but also other nutrients as phosphorus and sulphur have been shown to induce lipid accumulation [12-15]. Oleaginous yeasts should preferably be able to grow to high cell densities combined with a high fatty acid content, have good growth characteristics at low $\mathrm{pH}$ and a broad temperature range (robust 
process conditions), which facilitate the process development for future industrial applications. Furthermore, the ability to grow on a broad spectrum of carbon sources make oleaginous yeasts economically interesting.

The aim of this study is to find new yeasts that meet the aforementioned criteria and are potentially suited for fatty acid production for industrial applications. To this extent 24 non-Saccharomyces yeast species were selected and tested for the above mentioned criteria. Some of these selected strains have been described as having an oleaginous character $[10,16-20]$.

After selection for growth rate, lipid accumulation capacity, ability to use different carbon sources, $\mathrm{pH}$ and temperature optimum, Schwanniomyces occidentalis was selected as the most promising strain.

\section{Results and discussion}

\section{Selection of strains by TLC analysis}

From a private collection 24 yeast strains were selected to investigate their possible oleaginous character, where for 4 of these strains 2 variants were included, resulting in a total of 28 yeasts tested (Table 1). Generally, it is considered that lipid accumulation is induced at a molar $\mathrm{C} / \mathrm{N}$ ratio greater than 20 [20]. Previously, it was shown that lipid accumulation in $R$. toruloides is observed at a $\mathrm{C} / \mathrm{N}$ ratio of 30 and increases with an $\mathrm{C} / \mathrm{N}$ ratio up to 120 using glucose as carbon source [21]. When growing $Y$. lipolytica on glucose at a $\mathrm{C} / \mathrm{N}$ ratio of 50 a lipid content of $36 \%$ is reached [22]. In T. cutaneum a slight increase in lipid content was reached when increasing the $\mathrm{C} / \mathrm{N}$ ratio from 60 to 180 , followed by a sharp decrease when the $\mathrm{C} / \mathrm{N}$ ratio was further increased to 200 [23]. Furthermore, for $C$. freyschussi similar lipid content was reached at a $\mathrm{C} / \mathrm{N}$ ratios of 52 and 100 whilst an increase to $\mathrm{C} / \mathrm{N} 200$ had a negative effect on lipid content [24]. Not only the $\mathrm{C} / \mathrm{N}$ ratio but also type of the carbon and nitrogen sources used can have an impact on lipid production $[22,25]$. Therefore, in this study screening for novel oleaginous yeasts was performed using medium with a $\mathrm{C} / \mathrm{N}$ ratio of 75 , without optimizing growth conditions for each individual strain, using glucose as carbon and ammonium chloride as nitrogen source. The strains listed in Table 1 were cultivated in C/N 75 medium for three days. Cell mass was harvested and dry weight content and triacylglyceride content was determined after saponification.

In Fig. 1 the fatty acid content after saponification of the different strains is visualised by thin layer chromatography (TLC) using oleic acid as a positive control. Since equal amounts of dry cell mass were used, the intensity of the spot represents the triacylglyceride content per gram dry weight. From the TLC analysis, 10 strains could be identified as strains with a high triacylglyceride content, viz.; $H$. californica, $P$. anomala, T. delbrueckii, $H$. beijerinckii, $C$.
Table 1 Strains used in this study

\begin{tabular}{|c|c|c|}
\hline No. & Strain names & Culture collection \\
\hline 1 & Hansenula californica & CBS 5760 \\
\hline 2 & Candida glabrata & CBS 2663 \\
\hline 3 & Kluyveromyces phaffii & CBS 4417 \\
\hline 4 & Pichia angusta & CBS 4732 \\
\hline 5 & Torulopsis glabrata & own collection/HBC14 \\
\hline 6 & Pichia anomala & CBS 5759 \\
\hline 7 & Candida glabrata & CBS 2192 \\
\hline 8 & Candida lipolytica & own collection/HBC08 \\
\hline 9 & Torulopsis glabrata & CBS 858 \\
\hline 10 & Torulaspora delbrueckii & own collection/HBC36 \\
\hline 11 & Hansenula beijerinckii & CBS 2564 \\
\hline 12 & Candida tropicalis & own collection/HBC07 \\
\hline 13 & Yarrowia lipolytica & CBS 6124 \\
\hline 14 & Candida lusitaniae & IFFI 01461 \\
\hline 15 & Pichia silvicola & CBS 1706 \\
\hline 16 & Schwanniomyces occidentalis & CBS 2864 \\
\hline 17 & Sporobolomyces roseus & CBS 2841 \\
\hline 18 & Metschinikowia pulcherrima & CBS 5534 \\
\hline 19 & Candida bombicola & ATCC 22214 \\
\hline 20 & Candida intermedia & CBS 572 \\
\hline 21 & Candida tropicalis & CBS 94 \\
\hline 22 & Kloeckera africana & CBS 277 \\
\hline 23 & Pichia petersonii & CBS 5556 \\
\hline 24 & Lodderomyces elongisporus & CBS 2605 \\
\hline 25 & Kloeckera apiculata & CBS 104 \\
\hline 26 & Waltomyces lipofer & CBS 5841 \\
\hline 27 & Yarrowia lipolytica & CBS 2073 \\
\hline 28 & Crypotococcus curvatus & CBS 570 \\
\hline
\end{tabular}

tropicalis (12), S. occidentalis, L. elongisporus, W. lipofer, $Y$. lipolytica (27) and C. curvatus.

In Fig. 2 the final cell mass concentrations of the various strains are shown. Based on the results of Figs. 1 and 2, five strains were selected for further research, viz.; P. anomala, T. delbrueckii, $H$. beijerinckii, S. occidentalis and $W$. lipofer. Selection was based on a high content of triacylglycerides combined with a high cell mass concentration. The strain $L$. elongisporus met the criteria, but was not selected due to its suspected potential pathogenic character [26]. In addition based on literature $S$. cerevisiae was taken along as negative control.

\section{Growth of selected strains at various temperatures}

Strains used in large scale production processes should preferably be robust. Robustness of a strain is defined as the possibility to withstand process disturbances (e.g. temperature and $\mathrm{pH}$ variations), without having a large 


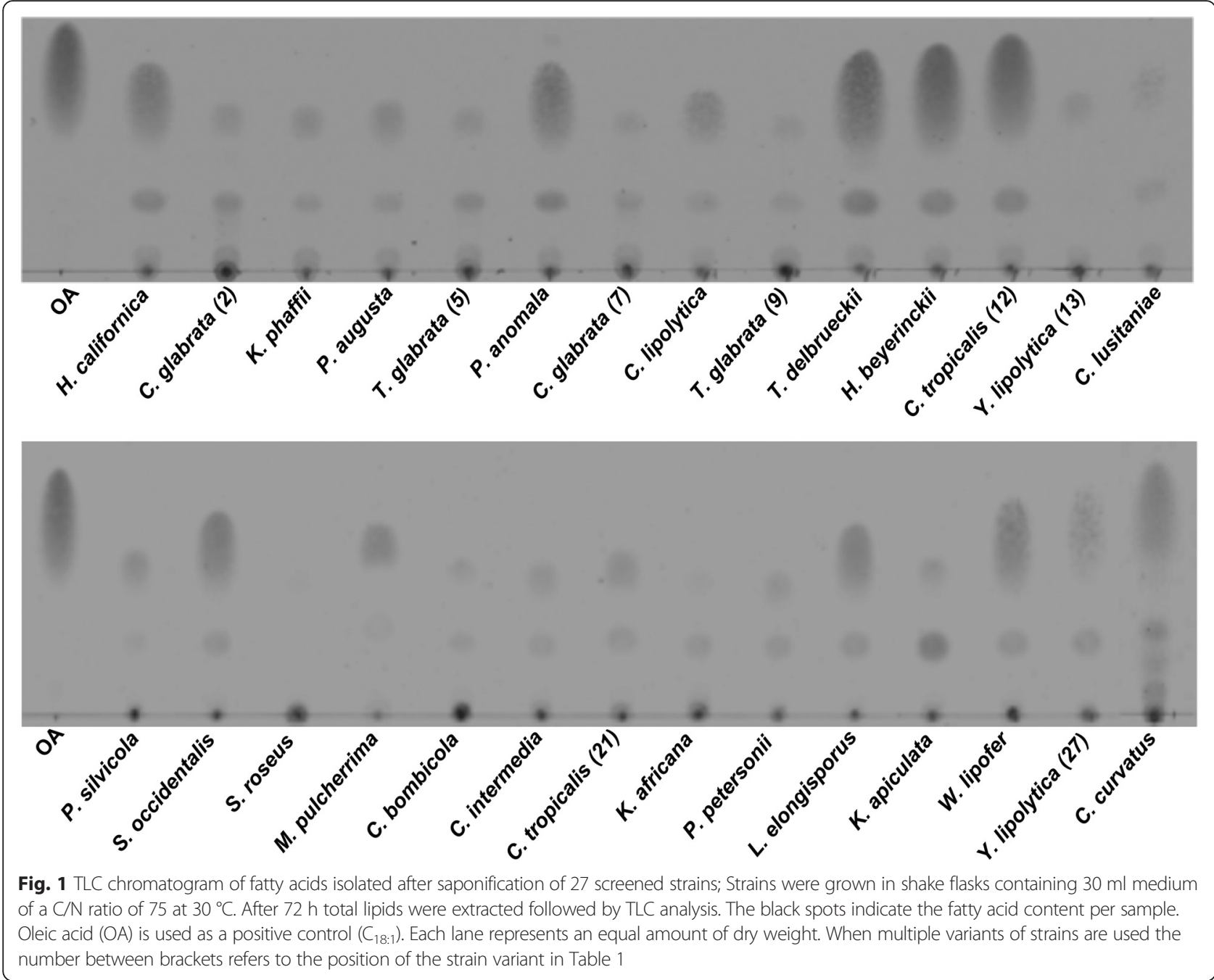

influence on the productivity of the process. The effect of temperature $(\mathrm{T})$ on cell growth was investigated for the selected yeast strains. A relatively broad $\mathrm{T}$ range at which the strains are still capable to grow without major changes in growth characteristics is desired in a large scale production process. In other words a shift in the temperature process control should have little effect on the final process. Furthermore, the ability to grow at higher temperatures is preferred to decrease the amount of cooling needed for cultivation [27].

Temperature profiles (Fig. 3) were obtained as described in the methods section. From these graphs two types of strains could be identified. Strains with a relatively narrow temperature range and strains having a broad temperature range in which growth is marginally influenced. Selecting the temperature area in which the growth rate is $80 \%$ of the maximum value, it can be seen that strains $H$. beijerinckii and $S$. cerevisiae have a narrow optimum, with approximately a $5{ }^{\circ} \mathrm{C}$ bandwidth around the maximum growth. For all the other strains this bandwidth ranges from $7{ }^{\circ} \mathrm{C}$ to $9{ }^{\circ} \mathrm{C}$, which is almost twice as broad (see dashed rectangles in Fig. 3). Based on the temperature profiles $S$. occidentalis, $P$. anomala, $W$. lipofer and $T$. delbrueckii are the most robust of the strains tested.

\section{Growth on different carbon sources}

Production of bio-based materials should preferably be performed using renewable and low cost carbon sources (often harbouring C5-sugars e.g. xylose and arabinose). The results of the growth potential of all strains on various carbon sources is displayed in Table 2.

From Table 2 it can be concluded that from the strains tested $S$. occidentalis can grow on all carbon sources used in this study except cellulose and hemi-cellulose, which requires the action of multiple enzymes: exo,1,4$\beta$-D-glucanase; endo,1,4- $\beta$-D-glucanase; cellobiohydolase and $\beta$-D-glucosidase, which are not commonly found in yeast $[28,29]$. However, also some typical fungal characteristics can be observed in this strain like growth on 


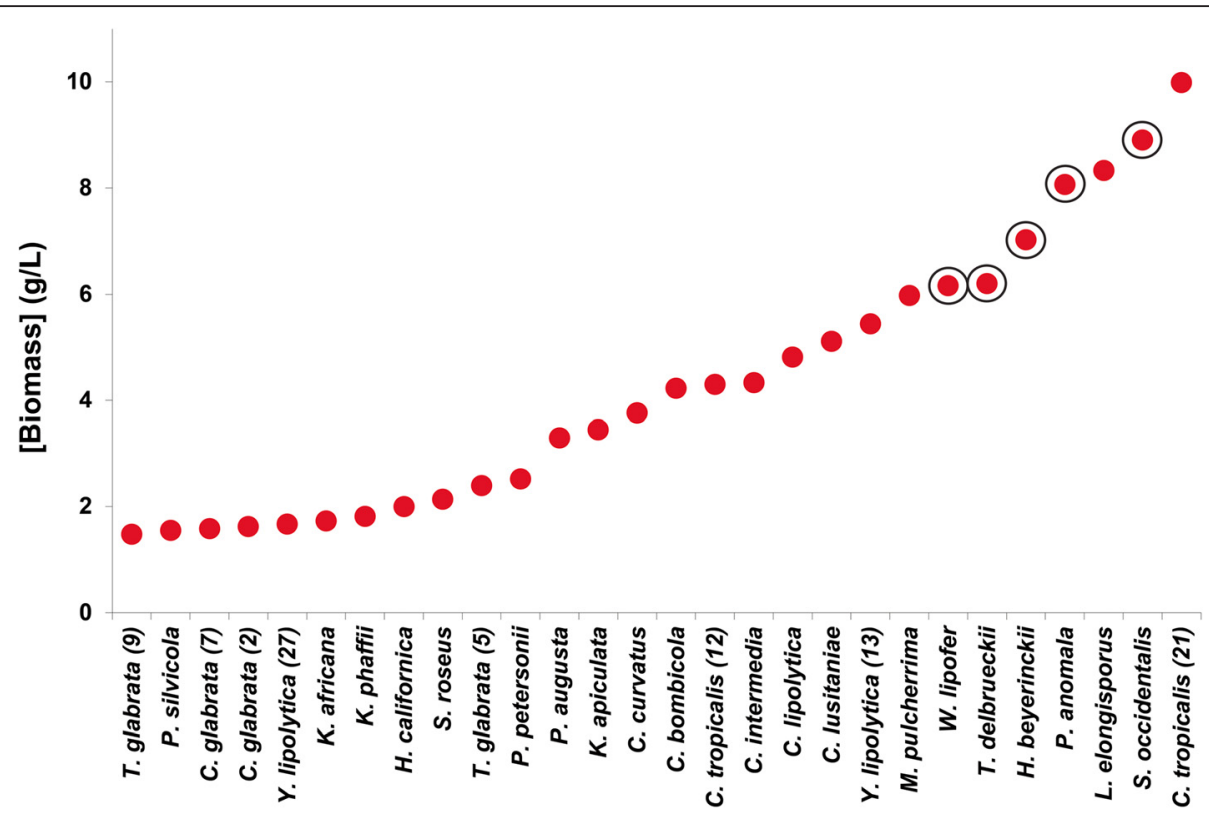

Fig. 2 Final biomass mass concentrations after three days of growth; Strains were grown in shake flasks containing $30 \mathrm{ml}$ medium of a C/N ratio of 75 at $30^{\circ}$. After $72 \mathrm{~h}$ of growth the biomass concentrations were determined. Strains are ordered in increasing amounts of biomass concentration. When multiple variants of strains are used the number between brackets refers to the position of the strain variant in Table 1. Five promising fatty acid producing strains are indicated with a circle

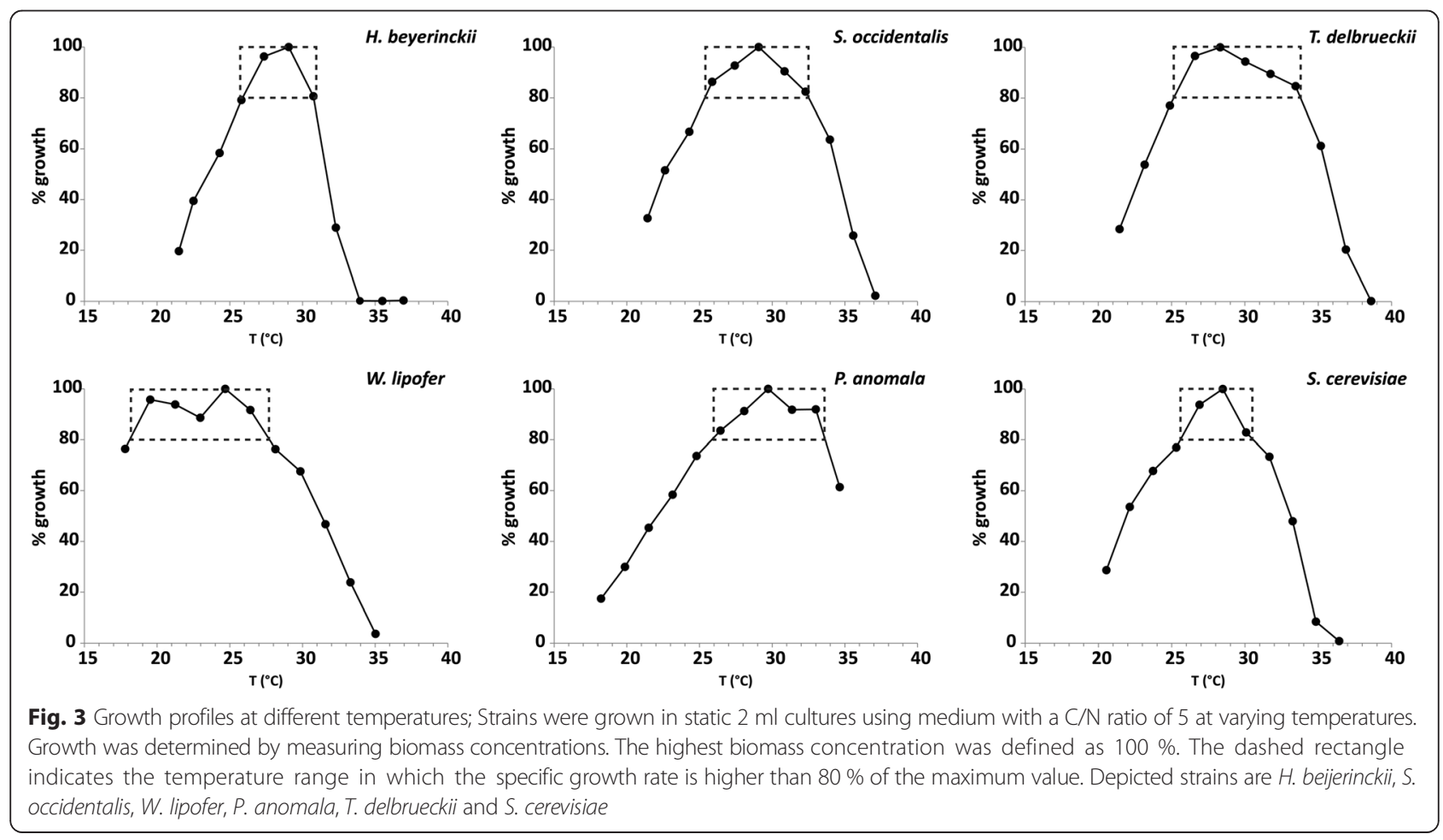


Table 2 Growth on agar plates containing different carbon sources

\begin{tabular}{|c|c|c|c|c|c|c|}
\hline Carbon source & S. occidentalis & W. lipofer & H. beijerinckii & P. anomala & T. delbrueckii & S. cerevisiae \\
\hline Glucose & + & + & + & + & + & + \\
\hline Fructose & + & + & + & + & + & + \\
\hline Galactose & + & + & + & + & + & + \\
\hline Arabinose & + & + & - & - & - & - \\
\hline Xylose & + & + & + & - & - & - \\
\hline Glycerol & + & + & + & + & + & - \\
\hline Sucrose & + & + & + & + & + & + \\
\hline Lactose & + & - & - & - & - & - \\
\hline Maltose & + & + & + & + & + & + \\
\hline Cellobiose & + & + & + & + & - & - \\
\hline Starch & + & - & - & - & - & - \\
\hline Inulin & + & + & + & + & + & - \\
\hline Xylan & - & - & - & - & - & - \\
\hline Cellulose & - & - & - & - & - & - \\
\hline No C source & - & - & - & - & - & - \\
\hline
\end{tabular}

starch that can only be achieved in the presence of glucoamylase activity, which is normally present in filamentous fungi and absent in yeasts. These findings are in line with the presence of glucoamylase activity which was already confirmed in S. occidentalis [30]. Striking was also the growth on cellobiose requiring $\beta$-glucosidase activity, which is part of the cellulolytic enzyme activity of fungi but not of that of yeasts. The genome of S. occidentalis was sequenced and assembled and the presence of a $\beta$-glucosidase gene having an identity of $77 \%$ with the $\beta$-glucosidase sequence of Scheffersomyces stipitis CBS 6054 (XP_001387646) was confirmed using tblastn. Growth on glycerol was tested, since it is an abundantly available side product obtained from biodiesel production. All strains except $S$. cerevisiae were able to grow on glycerol. The results of carbon source utilization by $\mathrm{S}$. occidentalis correspond with a recent study in which different oleaginous yeast species were screened for carbon source utilization and inhibitory tolerance in order to select yeasts suitable for specific industrial applications [31]. In the aforementioned study of Sitepu et al., S. occidentalis was found to be resistant to inhibitors at concentrations that are common in lignocellulosic hydrolysates (e.g. 2 g/l HMF, $1 \mathrm{~g} / \mathrm{l}$ furfural and 2,5 g/l acetic acid) thereby indicating its potential to utilize these carbon sources for lipid production.

Genetic engineering of oleaginous yeasts is frequently used to expand substrate utilization and further increase lipid content and productivity. The oleaginous yeast $Y$. lipolytica is unable to utilize starch and by the combined expression of alpha-amylase and glucoamylase growth on starch led to a fatty acid accumulation of $21 \%$ which was further increased to $27 \%$ after media optimizations
[32]. Furthermore, Tai and Stephanopoulus report that co-expression of ACC1 and DGA1 increases fatty acid content from $8.77 \%$ to $41.4 \% \%$ in Y. lipolytica [33]. A similar co-expression of ACC1 and DGA1 was performed in $R$. toruloides which increased lipid content from $31.3 \%$ to $61.1 \%$ [34]. Of the 5 strains tested only S. occidentalis is genetically accessible thereby indicating the potential to increase its fatty acid content, yield and carbon utilization $[35,36]$.

\section{Analysis of yeast cell mass}

The five selected strains and $S$. cerevisiae (negative control) were cultivated in media with different $\mathrm{C} / \mathrm{N}$ ratios for three days. Cell mass was harvested and quantitatively analysed for triacylglycerides content using gas chromatography (see Additional file 1 for fatty acid composition of these strains). Results are shown as a function of the $\mathrm{C} / \mathrm{N}$ ratio of the medium in Fig. 4. Fatty acid per dry weight content of all strains, except $S$. cerevisae, increased with an increasing $\mathrm{C} / \mathrm{N}$ ratio. The maximum lipid accumulation was $319 \mathrm{~g} / \mathrm{kg}$ reached by $T$. delbrueckii at a $\mathrm{C} / \mathrm{N}$ ratio of 75 whereas the minimum lipid accumulation was $152 \mathrm{~g} / \mathrm{kg}$ reached by $P$. anomala at a $\mathrm{C} / \mathrm{N}$ ratio of 90. Typical fatty acid content reached by oleaginous yeasts is higher and ranges from $360 \mathrm{~g} / \mathrm{kg}$ for $Y$. lipolytica, $580 \mathrm{~g} / \mathrm{kg}$ for C. curvatus to $720 \mathrm{~g} / \mathrm{kg}$ for $R$. glutinis [37]. The lower fatty acid content in this study could be attributed to the fact that cultivation conditions are not optimized. As previously demonstrated by Calvey et al. in $L$. starkeyi both the initial $\mathrm{C} / \mathrm{N}$ ratio and the agitation rate can have an impact on lipid accumulation and by lowering the agitation rate from $300 \mathrm{rpm}$ to $200 \mathrm{rpm}$ lipid accumulation was increased from $28.43 \%$ to $54.85 \%$ [38]. 


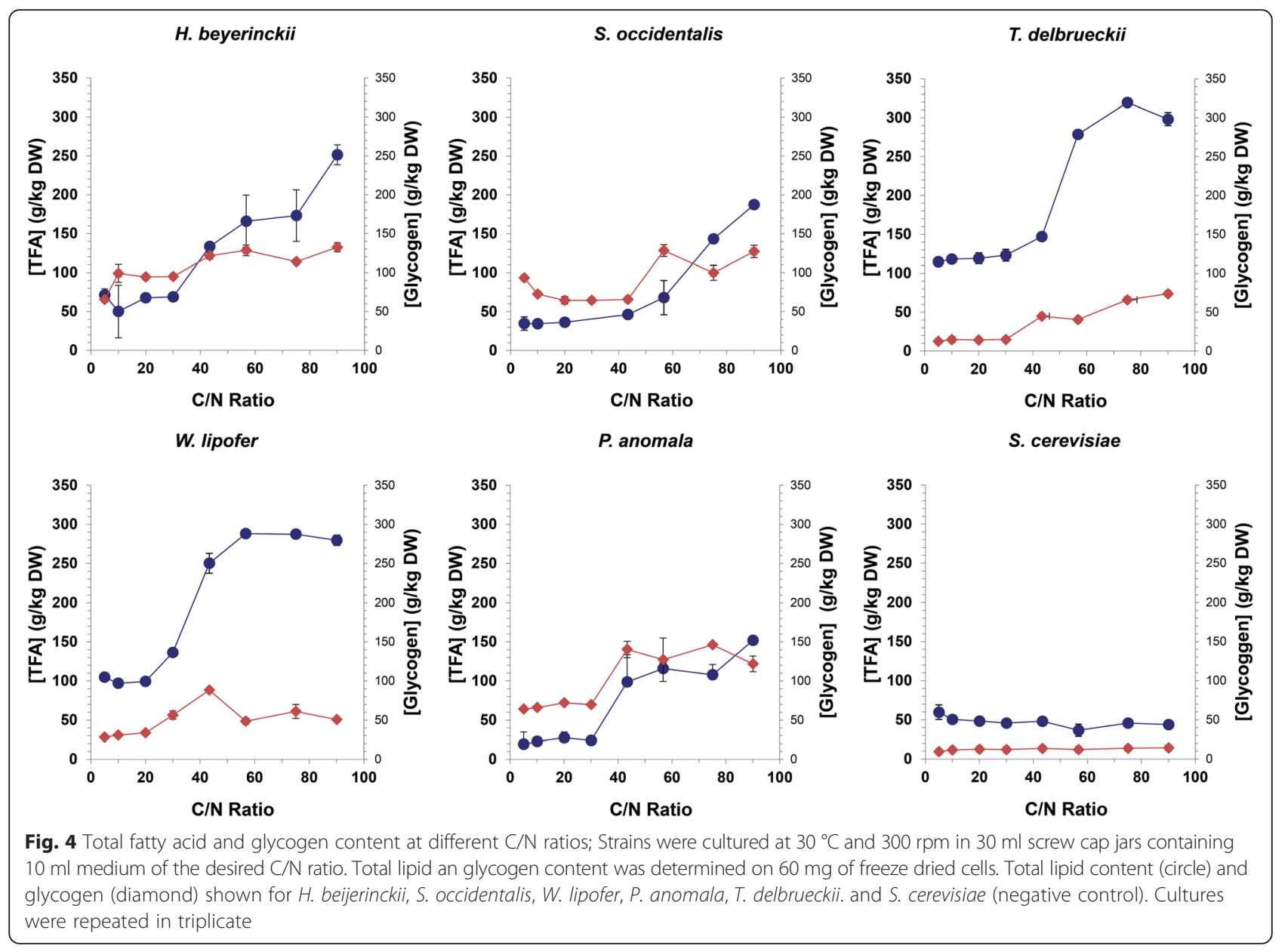

Furthermore, in L. starkeyi medium optimization while utilizing a mixture of glucose and xylose increased lipid content from $38.8 \%$ to $61.5 \%$ indicating that optimal lipid production can be achieved by further optimizations [39]. However, it has to be noted that comparison of triacylglyceride content with other studies described in literature is difficult, since they are highly dependent on used culture conditions and $\mathrm{C} / \mathrm{N}$ ratios.

To analyse the overall potential of triacylglyceride production the glycogen content per cell mass was also measured (Fig. 4). Cells undergoing nitrogen starvation are able to channel their carbon into several compounds such as lipids and glycogen [40]. Glycogen production under nitrogen starvation indicates that lipid concentrations could potentially be increased by channeling carbon from glycogen to lipid production via metabolic engineering or by changing culture condition [41]. All strains tested were able to accumulate glycogen at different $\mathrm{C} / \mathrm{N}$ ratio's. High glycogen contents were observed in P. anomala, H. beyerinckii and S. occidentalis, ranging from $125 \mathrm{~g} / \mathrm{kg}$ to $146 \mathrm{~g} / \mathrm{kg}$. The $S$. cerevisiae strain contained low amounts of glycogen which is in line with the fact that in S. cerevisiae production of trehalose is favoured over glycogen under nitrogen depletion [42].

Taken together all of the aforementioned criteria e.g. lipid content, growth on carbon sources, temperature and genetic accessibility we selected $S$. occidentalis as the most versatile strain.

A fed-batch fermentation of $S$. occidentalis was performed starting with an initial $\mathrm{C} / \mathrm{N}$ ratio of 75 . Maximal lipid content reached in the fed-batch fermentation was $41.9 \%$, lipid productivity was $0,083 \mathrm{~g} / \mathrm{l}$.h while DCW produced was $19,01 \mathrm{~g} / \mathrm{l}$ in $96 \mathrm{~h}$ (Table 3).

In comparison the maximal lipid content in S. occidentalis of $41.9 \%$ is higher than that of $Y$. lipolytica $36.73 \%$ when grown in a fed-batch fermentation using glucose, however it has to be noted that the initial $\mathrm{C} / \mathrm{N}$ ratio for $Y$. lipolytica was 50 [22]. Furthermore, the total amount of lipids produced by $L$. starkeyi on glucose at an initial $\mathrm{C} / \mathrm{N}$ ratio of 72 is slightly higher than for $S$. occidentalis $8.00 \mathrm{~g} / \mathrm{l}$ versus $10.03 \mathrm{~g} / \mathrm{l}$ [38]. Both $R$. glutinis and $R$. toruloides surpass S.occidentalis both in lipid content (64.00\% and $58.60 \%$ respectively) and in lipid productivity $(0.950 \mathrm{~g} / \mathrm{l} . \mathrm{h}$ and $0.360 \mathrm{~g} / \mathrm{l} . \mathrm{h}$ respectively). Via medium optimization and genetic engineering both 
Table 3 Productivity of fed-batch fermentations of oleaginous yeasts grown on glucose

\begin{tabular}{|c|c|c|c|c|c|c|c|c|c|c|}
\hline Strain & Substrate & $\begin{array}{l}\text { Initial C:N } \\
\text { ratio }\end{array}$ & $\begin{array}{l}\text { Culture } \\
\text { time (h) }\end{array}$ & $\begin{array}{l}\text { DCW produced } \\
(\mathrm{g} / \mathrm{l})\end{array}$ & $\begin{array}{l}\text { Lipids produced } \\
(\mathrm{g} / \mathrm{l})\end{array}$ & Lipid \% & $\begin{array}{l}\text { Lipid yield } \\
\text { (g/g sugar) }\end{array}$ & $\begin{array}{l}\text { Lipid productivity } \\
(\mathrm{g} / \mathrm{l} / \mathrm{h})\end{array}$ & $\begin{array}{l}\text { DCW productivity } \\
(\mathrm{g} / \mathrm{l} / \mathrm{h})\end{array}$ & Reference \\
\hline S. occidentalis & Glucose & 75 & 96 & 19.00 & 8.00 & 41.90 & 0.120 & 0.083 & 0.198 & This study \\
\hline L. starkeyi & Glucose & 72 & & 18.28 & 10.03 & 54.85 & 0.170 & 0.060 & 0.112 & [39] \\
\hline R. glutinis & Glucose & & 50 & 110.00 & 70.04 & 64.00 & & 0.950 & 1.408 & [41] \\
\hline Y. lipolytica & Glucose & 50 & 48 & 43.38 & 15.93 & 36.73 & 0.200 & 0.904 & 0.332 & {$[22]$} \\
\hline R. toruloides & Glucose & & & & 52.20 & 58.60 & 0.200 & 0.360 & & {$[45]$} \\
\hline
\end{tabular}

lipid content and productivity in S. occidentalis could be further increased [32, 39].

\section{Growth characteristics at low $\mathrm{pH}$}

Strains growing at relatively low $\mathrm{pH}$ values are more interesting, since infection problems can be reduced significantly in a large scale production process as can be seen in the dairy industry [43]. For this reason we investigated if $S$. occidentalis was able to grow by performing batch fermentations at a $\mathrm{pH}$ ranging from 2.5 to 7.5 . and determining biomass after $24 \mathrm{~h}$ of growth. The results demonstrate that $S$. occidentalis was able to grow in the $\mathrm{pH}$ range from 3.5 to 6.5 . Optimal growth was observed at a $\mathrm{pH}$ range of 4.5 to 6.5 with a biomass concentration of $10.5 \mathrm{~g} / \mathrm{l}$ to $12.7 \mathrm{~g} / \mathrm{l}$, whereas biomass concentrations at $\mathrm{pH} 3.5$ where $8.0 \mathrm{~g} / \mathrm{l}$.

\section{Conclusions}

The aim of this study was to select strains with a high lipid production, broad temperature range for growth, the ability to use a wide variety of carbon sources and genetic accessibility. Selection based on these criteria resulted in the selection of $S$. occidentalis as the most promising strain for industrial applications due to its ability to grow at a broad temperature and $\mathrm{pH}$ range and the ability to utilize many different carbon sources. The fatty acid production was not optimized in this study and leaves room for further improvement by optimizing process conditions and via metabolic engineering.

\section{Methods}

\section{Strains and media}

Strains used in this study are described in Table 1. Strains were inoculated on YPD slants (1\% yeast extract, 2 peptone and $2 \%$ glucose), grown at $30{ }^{\circ} \mathrm{C}$ and stored at $4{ }^{\circ} \mathrm{C}$ prior to use. A small amount of cells from the slants was resuspended in water, followed by centrifugation to remove any medium components. This cell suspension was used as an inoculum for growth experiments (typical seed rate was $0.01 \%$ ).

The composition of the $\mathrm{C} / \mathrm{N} 75$ medium $(75 \mathrm{~mol} \mathrm{C} /$ mol N) was: glucose.aq $33 \mathrm{~g} / \mathrm{l}, \mathrm{NH}_{4} \mathrm{Cl} 0.139 \mathrm{~g} / \mathrm{l}$, yeast extract (Gistex LS from DSM, @ $10 \%$ N) $1.5 \mathrm{~g} / \mathrm{l}, \mathrm{KH}_{2} \mathrm{PO}_{4}$ $3.2 \mathrm{~g} / \mathrm{l}, \quad \mathrm{MgSO}_{4} \cdot 7 \mathrm{H}_{2} \mathrm{O} 1.0 \mathrm{~g} / \mathrm{l}$. Glucose was sterilised separately from the other medium ingredients $(20 \mathrm{~min}$, $121{ }^{\circ} \mathrm{C}$ ). Filter sterilised biotin was added at a concentration of $0.02 \mathrm{mg} / \mathrm{l}$. Adjustment of the $\mathrm{C} / \mathrm{N}$ content of the medium was obtained by decreasing the $\mathrm{NH}_{4} \mathrm{Cl}$ content. With this yeast extract medium a $\mathrm{C} / \mathrm{N}$ ratio of $90 \mathrm{~mol}$ $\mathrm{C} / \mathrm{mol} \mathrm{N}$ could be obtained, without varying the yeast extract content.

\section{Temperature gradient}

Yeast strains were grown in static $2 \mathrm{ml}$ cultures $\mathrm{C} / \mathrm{N} 5$ medium (addition of $9.7 \mathrm{~g} / \mathrm{l} \mathrm{NH}_{4} \mathrm{Cl}$ ), using a temperature gradient block, which applies a gradient from 20 to $40{ }^{\circ} \mathrm{C}$. After two days of cultivation the $\mathrm{OD}_{600 \mathrm{~nm}}$ was measured. $\mathrm{OD}_{600 \mathrm{~nm}}$ values were corrected for the amount of evaporation, which was determined by weighing the culture tubes prior and after cultivation. The growth was expressed as relative value against the maximum obtained value.

\section{Growth on various carbon sources}

Agar plates were made from Yeast Nitrogen Base (YNB) medium (Roth art. no HP26.1) containing $2 \%$ agar (Roth art. no 5210.1), which were supplemented with $2 \%$ of the indicated carbon sources (see the results). Carbon sources were sterilised separately. Overnight cultures were diluted to an $\mathrm{OD}_{600 \mathrm{~nm}}$ of 0.1 and $10 \mu \mathrm{l}$ was spotted on the individual carbon source containing agar plates. Duplicate plates were incubated at $30{ }^{\circ} \mathrm{C}$ and checked daily for growth for $72 \mathrm{~h}$. Growth in the spotted areas was analysed on plates with different carbon sources using plates lacking carbon source as a negative control.

\section{$\mathrm{C} / \mathrm{N}$ ratio experiments}

$10 \mathrm{ml}$ of the desired $\mathrm{C} / \mathrm{N}$ medium was inoculated with a washed suspension of cells (typical seed rate was $0.01 \%$ ) and grown in $30 \mathrm{ml}$ plastic flat bottomed screw cap jars (VWR art. no. 216-2694, diameter $3 \mathrm{~cm}$ and height $7 \mathrm{~cm}$ ) with a cotton wool stopper in the cap. The jars were incubated on a rotary shaker (type Innova, New Brunswick Scientific) set at $300 \mathrm{rpm}$. After three days, the cells were harvested, washed and freeze dried for further analysis.

\section{Batch fermentations}

Batch fermentations were performed in 71 BioFlo115 fermenters using the $\mathrm{C} / \mathrm{N} 5$ medium. The $\mathrm{pH}$ was controlled 
with $2 \mathrm{M} \mathrm{NaOH}$ or $1 \mathrm{M} \mathrm{H}_{3} \mathrm{PO}_{4}$. During the fermentation process $4 \mathrm{ml}$ samples were taken using an automatic sampler (Gilson art. no. F203B). Collected samples were cooled to $1{ }^{\circ} \mathrm{C}$ to quench the metabolism. Samples were used for dry weight determination and the presence of residual glucose was analysed on a Cobas Mira Plus using the Horiba ABX Pentra Glucose HK CP reagent (art. no. A11A01667).

\section{Fed batch fermenation}

A single colony was used to inoculate $100 \mathrm{ml}$ of C/N 75 medium. After $24 \mathrm{~h}$ growth at $30{ }^{\circ} \mathrm{C}$ and $250 \mathrm{rpm}$ agitation the inoculum was transferred into a $1,25 \mathrm{~L}$ fermenter.

Fed-batch fermentation was performed in 11 Bioflo 115 fermenter using the $\mathrm{C} / \mathrm{N} 75$ medium. After depletion of the initial glucose concentration a glucose feed of $1,1 \mathrm{~g} / \mathrm{h}$ was established. The $\mathrm{pH}$ was controlled with $2 \mathrm{M} \mathrm{NaOH}$ or $1 \mathrm{M} \mathrm{H}_{3} \mathrm{PO}_{4}$. During the fermentation process $4 \mathrm{ml}$ samples were taken using an automatic sampler (Gilson art. no. F203B). Collected samples were cooled to $1{ }^{\circ} \mathrm{C}$ to quench the metabolism. Samples were used for dry weight determination and the presence of residual glucose was analysed on a Cobas Mira Plus using the Horiba ABX Pentra Glucose HK CP reagent (art. no. A11A01667).

\section{Total lipids extraction and TLC analysis}

$500 \mu \mathrm{l}$ of $50 \% \mathrm{NaOH}$ was added to a $2 \mathrm{ml}$ cell suspension in capped glass tubes. Tubes were incubated overnight at $100{ }^{\circ} \mathrm{C}$. After cooling down $1.1 \mathrm{ml}$ of $37 \% \mathrm{HCl}$ was added to liquefy the soap. The mixture was extracted with $5 \mathrm{ml}$ of ethyl acetate by vortexing, followed by centrifugation at $2000 \mathrm{~g}$ for $5 \mathrm{~min}$. The top layer was transferred to another tube and the excess of ethyl acetate was evaporated by an air stream at $50{ }^{\circ} \mathrm{C}$. After complete drying, $100 \mu \mathrm{l}$ of ethyl acetate was added to dissolve the residue. To compare the strains, the residues were further diluted to obtain normalised concentrations according to their cell mass content. In total $30 \mathrm{mg}$ of cells were used. Thin layer chromatography was used to separate and visualise the residues obtained from saponification. Diluted samples $(10 \mu \mathrm{l})$ were loaded on TLC plates (MERCK art. no. code 1.05554.0001) and left at room temperature for drying. Plates were run in a pre-equilibrated TLC container with a mixture of hexane : ethyl acetate : acetic acid $=90: 10$ : 1 as the mobile phase. After $10 \mathrm{~cm}$ of front migration the plates were removed from the TLC container and air dried. To visualise the products the dried plates were sprayed with concentrated sulphuric acid : methanol $=1$ : 1 and placed in an oven at $150{ }^{\circ} \mathrm{C}$ for approximately $30 \mathrm{~min}$. Oleic acid was used as a control.

\section{Fatty acid determination with gas chromatography}

The total fatty acid content was measured according to a modified version of the method described by
Kang and Wang (2005). To $30 \mathrm{mg}$ of freeze dried cells in a capped test tube with screw cap (VWR art. no. SCERE5100160011G1 and SCERKSSR15415BY100) $1 \mathrm{ml}$ $\mathrm{BF}_{3} /$ methanol reagent (Merck art. no. 8.01663.0500) and $1 \mathrm{ml}$ heptane (Acros organics art. no. 120340025) was added. After overnight incubation at $70{ }^{\circ} \mathrm{C} 2 \mathrm{ml}$ water was added and mixed. Subsequently, the tubes were centrifuged at $2000 \mathrm{~g}$ for $5 \mathrm{~min}$, and the upper (heptane) layer was transferred to a GC vial and analysed on methylated fatty acids by using a Focus-GC (Interscience) equipped with FID. GC was equipped with a Stabilwax Column (Restek art. no. 10624) and uses hydrogen as carrier gas. The sum of the methylated fatty acids was quantified using methylheptadocanic acid as a standard.

\section{Glycogen analysis}

Glycogen was analysed according to a modified method as described by Aklujkar et al. [44]. To $30 \mathrm{mg}$ of dry weight cells $500 \mu \mathrm{l}$ of $2 \mathrm{M} \mathrm{NaOH}$ was added followed by boiling for $1 \mathrm{~h}$. To neutralize this mixture, $60 \mu \mathrm{l}$ of $9 \mathrm{M}$ $\mathrm{H}_{2} \mathrm{SO}_{4}$ and $600 \mu \mathrm{l} 1 \mathrm{M} \mathrm{NaAc} / \mathrm{HAc}$ buffer $(\mathrm{pH} 4,5)$ were added. To $400 \mu \mathrm{l}$ of sample, 50 units of glucoamylase (Novozymes art. no. NS22035) were added and incubated at $50{ }^{\circ} \mathrm{C}$ for $1 \mathrm{~h}$. The final glucose concentration of the mixture was measured with and without amyloglucosidase treatment on a Cobas Mira Plus using the Horiba ABX Pentra Glucose HK CP reagent (art. no. A11A01667). Maltose was used as a positive control to check the activity of the amyloglucosidase.

\section{Dry weight analysis}

A culture sample of $10 \mathrm{ml}$ was weighed on an analytical balance in a pre-weighed tube and centrifuged at $3500 \mathrm{~g}$ for $10 \mathrm{~min}$. The cell pellet was washed with water, $20 \%$ of the original volume, and centrifuged again $(3500 \mathrm{~g}$ for $10 \mathrm{~min}$.). The pellet was resuspended in $0.5 \mathrm{ml}$ of water and frozen at $-20{ }^{\circ} \mathrm{C}$ for $4 \mathrm{~h}$. Cell pellets were dried by lyophilisation for $24 \mathrm{~h}$ on a Christ freeze dryer (type 2-4 LD) and dried pellets were weighed on an analytical balance. Biomass concentration is determined by dividing the weight of the dried biomass by the weight of the culture sample. After dry weight quantification, the freeze dried cells were used for total fatty acid and glycogen analysis.

\section{Additional file}

Additional file 1: Table S1. Fatty acid composition of strains cultured using medium with a C/N ratio of 75. Description: Fatty acid composition of tested strains depicted as \% (w/W) of the total fatty acid levels. Experiments were performed in triplicate. (PDF $224 \mathrm{~kb}$ ) 
triacylglycerides; TLC, thin layer chromatography; YNB, yeast nitrogen base; YPD, yeast-petone-dextrose broth

\section{Acknowledgements}

The authors would like to thank Niek Klein for his technical assistance.

\section{Funding}

This research project was financially supported by HAN University of Applied Sciences and SIA.

\section{Authors' contributions}

$D L, N v B, L P, E v d Z$ and NJvD performed all experiments. DL, NvB, LP, EvdZ, NJvD, DM drafted the manuscript. RW and CL revised the manuscript. All authors read and approved the final manuscript.

\section{Competing interests}

The authors declare that they have no competing interests.

\section{Consent for publication}

Not applicable.

\section{Ethics approval and consent to participate}

Not applicable.

\section{Author details}

${ }^{1}$ HAN BioCentre, University of Applied Sciences, P.O. Box 6960, 6503 GL Nijmegen, The Netherlands. ${ }^{2}$ Bioprocess Engineering, Wageningen University and Research Centre, P.O. Box 8129, 6700 EV Wageningen, The Netherlands. ${ }^{3}$ University of Nordland, Faculty of Biosciences and Aquaculture, N-8049 Bodø, Norway.

Received: 12 August 2015 Accepted: 23 May 2016 Published online: 27 May 2016

\section{References}

1. Ageitos JM, Vallejo JA, Veiga-Crespo P, Villa TG. Oily yeasts as oleaginous cell factories. Appl Microbiol Biotechnol. 2011:90:219-1227.

2. Ratledge C. Single Cell Oil. Enzyme Microb Technol. 1982;4:58-60.

3. Rattray JBM. Biotechnology and the fats and oils industry - an overview. JAOCS. 1984:61:1701-12.

4. Belgacem MN, Gandini A. Chapter 3 - Materials from Vegetable Oils: Major Sources, Properties and Applications. In Monomers, polymers and pomposites from renewable resources. First ed. Great Britain: Elsevier; 2008 pp. 39-66.

5. Beopoulos A, Verbeke J, Bordes F, Guicherd M, Bressy M, Marty A, Nicaud JM. Metabolic engineering for ricinoleic acid production in the oleaginous yeast Yarrowia lipolytica. Appl Microbiol Biotechnol. 2014;98:251-62.

6. Draaisma RB, Wiiffels RH, Slegers PM, Brentner LB, Roy A, Barbosa MJ. Food commodities from microalgae. Curr Opin Biotechnol. 2013;24:167-77.

7. Luque R, Lovett JC, Datta B, Clancy J, Campelo JM, Romero AA. Biodiesel as feasible petrol fuel replacement: a multidisciplinary overview. Energy Enivron Sci. 2010;3:1706-21

8. Yuan W, Hansen AC, Zhang Q. Vapor pressure and normal boiling point predictions for pure methyl esters and biodiesel fuels. Fuel. 2005;84:943-50.

9. Ratledge C. Regulation of lipid accumulation in oleaginous micro-organisms. Biochem Soc Trans. 2002;30:1047-50.

10. Ratledge C, Cohen Z. Microbial and algal oils: Do they have a future for biodiesel or as commodity oils ? Lipid Technol. 2008;20:155-61.

11. Sitepu IR, Sestric R, Ignatia L, Levin D, German JB, Gillies LA, Almada LA, Boundy-Mills KL. Manipulation of culture conditions alters lipid content and fatty acid profiles of a wide variety of known and new oleaginous yeast. Bioresour Technol. 2013;144:360-9.

12. Papanikolaou S, Aggelis G. Lipids of oleaginous yeasts. Part I:Biochemistry of single cell oil production. Eur J Lipid Sci Technol. 2011;113:1031-51.

13. Gill CO, Hall MJ, Ratledge C. Lipid accumulation in an oleaginous yeast (Candida 107) growing on glucose in single-stage continuous culture. Appl Environ Microbiol. 1977;2:231-9.

14. Wu S, Hu C, Jin G, Zhao X, Zhao ZK. Phosphate-limitation mediated lipid production by Rhodosporidium toruloides. Bioresour Technol. 2010;101:6124-9.
15. Wu S, Zhao X, Shen H, Wang Q, Zhao ZK. Microbial lipid production by Rhodosporidium toruloides under sulfate-limited conditions. Bioresour Technol. 2011;102:1803-7.

16. Beopoulos A, Nicaud JM, Gailardin C. An overview of lipid metabolism in yeasts and its impact on biotechnological processes. Appl Microbiol Biotechnol. 2011;90:1193-206.

17. Daniel HJ, Otto RT, Binder M, Reuss M, Syldatk C. Production of sophorolipids from whey: development of a two-stage process with Cryptococcus curvatus ATCC 20509 and Candida bombicola ATCC 22214 using deproteinized whey concentrates as substrates. Appl Microbiol Biotechnol. 1999;51:40-5.

18. Johnson EA. Biotechnology of non-Saccharomyces yeasts- the basidiomycetes. Appl Microbiol Biotechnol. 2013;97:7563-77.

19. Meesters P, Huijberts GNM, Eggink G. High cell density cultivation of the lipid accumulating yeast Cryptococcus curvatus using glycerol as a carbon source. Appl Microbiol Biotechnol. 1996:45:575-9.

20. Papanikolaou S, Aggelis G. Lipids of oleaginous yeasts. Part II:Biochemistry of single cell oil production. Eur J Lipid Sci Technol. 2011;113:1052-73.

21. Nicaud JM, Coq A, Rossignol T, Morin N. Protocols for monitoring growth and lipid accumulation in oleaginous yeasts. Berlin Heidelberg: Springer Protocols Handbooks. 2014; pp. 1-17.

22. Fontanille P, Kumar V, Christophe G, Nouaille R, Larroche C. Bioconversion of volatile fatty acids into lipids by the oleaginous yeast Yarrowia lipolytica. Bioresourc Techno. 2012;114:443-9.

23. Chen XF, Huang C, Yang XY, Xiong L, Chen XD, Ma LL. Evaluating the effect of medium composition and fermentation condition on the microbial oil production by Trichosporon cutaneum on corncob acid hydrolysate. Bioresourc Techno. 2013;143:18-24.

24. Raimondi S, Rossi M, Leonardi A, Bianchi M, Rinaldi T, Amaretti A. Getting lipids from glycerol: new perspectives on biotechnological exploitation of Candida freyschussii. Microbial Cell Factories. 2014;13:83.

25. Kolouchová I, Sigle K, Schreiberová O, Masák J, Řezanka T. New yeast-based approaches in production of palmitoleic acid. Bioresourc Techno. 2015;192: 726-34

26. Bennet RJ. A Candida-based view of fungal sex and pathogenesis. Genome Biol. 2009;10:230.

27. Abdel-Fattah WR, Fadil M, Nigam P, Banat IM. Isolation of thermotolerant ethanologenic yeasts and use of selected strains in industrial scale fermentation in an Egyptian distillery. 2000:68:531-535.

28. Souza AC, Carvalho FP, Batista CF SE, Schwan RF, Dias DR. Sugarcane bagasse hydrolysis using yeast cellulolytic enzymes. J Microbiol Biotechnol. 2013:23:1403-12

29. Wei H, Wang W, Alahuhta M, Vander Wall T, Baker JO, Taylor LE, Decker SR, Himmel ME, Zhang M. Engineering towards a complete heterologous cellulose secretome in Yarrowia lipolytica reveals its potential for consolidated bioprocessing. Biotechnol Biofuels. 2014:7:148.

30. Sato F, Okuyama M, Nakai H, Mori H, Kimura A, Chiba S. Glucoamylase originating from Schwanniomyces occidentalis is a typical alpha-glucosidase. Biosci Biotechnol Biochem. 2005;69:1905-13.

31. Sitepu I, Selby T, Lin T, Zhu S, Boundy-Mills K. Carbon source utilization and inhibitor tolerance of 45 oleaginous yeast species. J Ind Microbiol Biotechnol. 2014:41:1061-70.

32. Ledesma-Amaro R, Dulermo T, Nicaud JM. Engineering Yarrowia lipolytica to produce biodiesel from raw starch. Biotechnol Biofuels. 2015:8:148.

33. Tai M, Stephanopoulos $G$. Engineering the push and pull of lipid biosynthesis in oleaginous yeast Yarrowia lipolytica for biofuel production. Metab Eng. 2013;15:1-9.

34. Zhang S, Skerker J, Rutter C, Maurer M, Arkin A, Rao C. Engineering Rhodosporidium toruloides for increased lipid production. Biotechnol Bioeng. 2015;113:1056-66.

35. Wang $T$, Lee $C$, Lee $B$. The molecular biology of Schwanniomyces occidentalis klocker. Crit Rev Biotechnol. 1999:19:113-43.

36. Alvaro-Benito M, Fernandez-Lobato M, Baronian K, Kunze G. Assessment of Schwanniomyces occidentalis as a host for protein production using the wide-range Xplor2 expression platform. Appl Microbiol Biotechnol. 2013;97:4443-56.

37. Ratledge C, Wynn J. The biochemistry and molecular biology of lipid accumulation in oleaginous microorganisms. Adv Appl Microbiol. 2002; $51: 1-51$.

38. Calvey C, Su Y, Willis L, McGee M, Jeffries T. Nitrogen limitation, oxygen limitation, and lipid accumulation in Lipomyces starkeyi. Bioresourc Technol. $2016 ; 200: 780-8$ 
39. Zhao X, Kong X, Hua Y, Feng B, Zhao Z. Medium optimization for lipid production through co-fermentation of glucose and xylose by the oleaginous yeast Lipomyces starkeyi. Eur J Lipid Sci Tech. 2008;110:405-12.

40. Cescut J, Fillaudeau L, Molina-Jouve C, Uribelarrea J. Carbon accumulation in Rhodotorula glutinis induced by nitrogen limitation. Biotechnol Biofuels. 2014;7:164.

41. Cupertino FB, Freitas FZ, de Paula RM, Bertolini MC. Ambient pH controls glycogen levels by regulation of glycogen synthase gene expression in Neurospora crassa. New insights into the pH signaling pathway. PLoS One. 2012; $7:$ e44258.

42. Hazelwood LA, Walsh MC, Luttik MA, Daran-Lapujade P, Pronk JT, Daran JM. Identity of the growth-limiting nutrient strongly affects storage carbohydrate accumulation in anaerobic chemostat cultures of Saccharomyces cerevisiae. Appl Enivron Microbiol. 2009;75:6876-85.

43. Suriyarachchi VR, Fleet GH. Occurrence and growth of yeasts in yoghurts. Appl Environ Microbiol. 1981;42:574-9.

44. Aklujkar PP, Sank SN, Arvindekar AU. A simplified method for the isolation and estimation of cell wall bound glycogen in Saccharomyces cerevisiae. J Inst Brew. 2008;114:205-8.

45. Zhao X, Hu C, Wu S, Shen H, Zhao Z. Lipid production by Rhodosporidium toruloides Y4 using different substrate feeding strategies. JIMB. 2011;38:627-32.

\section{Submit your next manuscript to BioMed Central} and we will help you at every step:

- We accept pre-submission inquiries

- Our selector tool helps you to find the most relevant journal

- We provide round the clock customer support

- Convenient online submission

- Thorough peer review

- Inclusion in PubMed and all major indexing services

- Maximum visibility for your research

Submit your manuscript at www.biomedcentral.com/submit

) Biomed Central 